$\begin{gathered}\text { ADVANCE RESEARCH JOURNAL OF SOCIAL SCIENCE } \\ \text { Volume 11 | Issue 1 | June, 2020 | 22-25 a ISSN-0976-5611 } \\ \text { REVIEw }\end{gathered}$
$\begin{gathered}\text { DOI: 10.15740/HAS/ARJSS/11.1/22-25 } \\ 0-1 \text { visit us : ww.researchjournal.co.in }\end{gathered}$

\title{
A review on role analysis of women in India and developed countries
}

M.V. Mokashi* and G. Chitagubbi ${ }^{1}$

Department of Human Development and Family Studies, College of Community Science, University of Agricultural Sciences Dharwad (Karnataka) India

${ }^{1}$ Department of Family Resource Management, College of Community Science, University of Agricultural Sciences, Dharwad (Karnataka) India

(Email:malavika.m17@gmail.com)

ARTICLE INFO :

Received : 27.04 .2020

Accepted : 18.05 .2020

\section{KEY WORDS :}

Gender inequality, Women status, Women empowerment

\section{HOW TO CITE THIS ARTICLE :}

Mokashi, M.V. and Chitagubbi, G. (2020). A review on role analysis of women in India and developed countries. Adv. Res. J. Soc. Sci., 11 (1): 22-25, DOI: 10.15740/ HAS/ARJSS/11.1/22-25.Copyright@ 2020:Hind Agri- Horticultural Society

*Author for correspondence

\begin{abstract}
In the modern socialist societies equality of status has been assigned to both women and men but still women live in perpetual subordination to the men. Ancient literatures showed evidence that; women are fully the equals of men as regards to access to and capacity for the highest knowledge. As the society got much more settled and was not subjected to the pressure of continuous invasion, the position of women became subject to deterioration. In the modern society, the women are still not given equality in the religious matters and property rights. The position of women in India and other countries has remained subordinate to men. The girl is given secondary position in the household, in respect of food, dress, schooling, healthcare etc. After attaining independence, the Indian constitution granted women equal rights as that of men but they were never been effective to bring a remarkable change in the status of modern women. Gender equality is an important issue of human rights and social justice not only in India but also in the world as a whole. It has been recognized that efforts to promote gender equality between men and women can along contribute to the overall development of human society, despite this consciousness and greater awareness of the role of women; they are treated equal to men in any society. The developments at the international level and plans of action taken by the United Nations contributed significantly towards development of women all over the world. There was also an emphasis on awareness about their rights and privileges, training for undertaking economic activities and providing employment opportunities for women.
\end{abstract}

